\title{
SHELF LIST OF THE
}

\section{UNION THEOLOGICAL SEMINARY LIBRARY}

This theological collection, unsurpassed in the United States, is strong, varied and specialized. Exegetical materials are to be found in abundance. Large holdings of incunabula and I6th century Bibles, Greek Testaments and Gospels embody 500 years of Bible translation, revision and publication. An excellent supporting rollection of books on the languages of interest to the Biblical scholar has been gathered. The chief strength of the Library lies in the historical field. Many ancient and most of the definitive editions of the Church Fathers, both Western and Oriental, are available. 203,385 cards. Io volumes.

$\$ 715.00$ (U.S.). $\$ 786.50$ (Outside U.S.).

Prospectus on request

G. K. HALL \& CO., 97 Oliver St., Boston 1o, Mass., U.S.A.

\section{URGENTLY REQUIRED}

THE SCOTTISH JOURNAL OF THEOLOGY

The following back numbers of the Journal are out of print. Will readers who have copies which they do not now require kindly advise the Publishers.

$194^{8}$ Volume I. Numbers 1,2 and 3.

1949 Volume 2. Number 2.

1952 Volume 5. Numbers $1,2,3$ and 4.

1953 Volume 6. Numbers $1,2,3$ and 4 .

OLIVER AND BOYD

Tweeddale Court, Edinburgh, I 